Informatika i sistemy upravleniya. - 2018. - No. 3(57). - P. 3-9.

Abakumov A.I. (abakumov@iacp.dvo.ru), Yakovlev A.A.

Institute of Automation and Control Processes

\title{
A MODEL OF THE IMMUNE RESPONSE TO VIRAL INFECTION
}

A mathematical model of human body immune response to viral infection has been elaborated and examined. The model demonstrates three main variants of the disease development: recovery, chronicity and death. Different variants of full recovery have been studied in detail.

Keywords: mathematical model, equilibrium, dynamics, virus, immune system.

DOI:10.22250/isu.2018.57.3-9

For citation:

Abakumov A.I., Yakovlev A.A. A MODEL OF THE IMMUNE RESPONSE TO VIRAL INFECTION // Informatika i sistemy upravleniya. - 2018. - No. 3(57). - P. 3-9. 